\section{Multispecies cover cropping promotes soil health in no-tillage cropping systems of North Carolina}

\section{A.J. Franzluebbers, S.W. Broome, K.L. Pritchett, M.G. Wagger, N. Lowder, S. Woodruff, and M. Lovejoy}

\begin{abstract}
Moving agricultural production systems toward a greater level of soil health is needed for sustainability. Conservation agricultural systems utilizing no or minimum tillage are an important step forward, but enhancing carbon (C) inputs with diverse cover crops and facilitating biologically active nitrogen $(\mathrm{N})$ cycling are also needed. Summer cash-crop systems, particularly in the warm-humid region of the southeastern United States, may benefit from multispecies winter cover cropping if sufficient biomass were produced. We implemented a research and demonstration project utilizing multispecies cover cropping in 15 counties of North Carolina during 2015 to 2019 to assess biomass production and its effect on surface-soil properties. Winter cover crop biomass production was variable among locations, but exceeded $3,790 \mathrm{~kg} \mathrm{ha}^{-1}$ in one-third of trials. Nitrogen contained in aboveground cover crop biomass exceeded $60 \mathrm{~kg} \mathrm{ha}^{-1}$ in the upper third of trials. Of 30 soil properties measured in each site-year $(n=31)$ at depths of 0 to 5 and 5 to $15 \mathrm{~cm}$, soil-test biological activity, C mineralization during 24 days, total soil $\mathrm{N}$, and Mehlich-III phosphorus (P) and potassium $(\mathrm{K})$ were most consistently affected when comparing multispecies cover cropping with either no or single-species cover cropping. Despite relatively short duration of evaluations (i.e., mostly one to two years), we were able to elucidate that winter multispecies cover cropping has potential to improve soil health conditions in the region. Soil-test biological activity demonstrated the living nature of soil and was sensitive to conservation agricultural management. The support of a hands-on farmer and adviser network encouraged success.
\end{abstract}

Key words: biomass production—carbon—nitrogen—on-farm research—organic mattersoil biological activity

\begin{abstract}
Cover cropping is part of a conservation strategy to keep soil covered and increase carbon (C) input to soil via photosynthesis during noncash-crop growing periods (Unger and Vigil 1998; Snapp et al. 2005). Overcoming water and nitrogen (N) availability limitations to succeeding cash crops were issues addressed in early research (Wagger 1989a; Ewing et al. 1991). Research and experience on farms have overcome some of these limitations when combining grass and legume cover crops (Ranells and Wagger 1997; Kaye et al. 2019) and better timing of cover crop termination (Wagger 1989b; Keene et al. 2017).
\end{abstract}

and enhance biological activity is through greater diversity of cover crops planted at the same time (i.e., multispecies cover cropping) (Finney and Kaye 2017). Hypotheses for using a diverse mixture of cover crop species rather than single species include the following: (1) better establishment of cover crops on land that is variable in moisture condition, soil texture, crop residue distribution, and terrain; (2) improved $\mathrm{C}$ and $\mathrm{N}$ balance of accumulated biomass from legumes that fix atmospheric $\mathrm{N}$ and grasses that absorb unused nutrients to avoid nutrient losses during the following cash-crop period; (3) more effective weed control from a diverse canopy with layered botanical structure and potentially greater leaf area index; (4) more diverse root distribution to explore surface and subsurface zones for water and nutrient extraction more effectively; and (5) biochemical diversity of accumulated biomass for feeding soil biology during decomposition.

Soil health is defined as the continued capacity of soil to function as a vital living ecosystem that sustains plants, animals, and humans (USDA NRCS n.d.). Indicators of soil health include a variety of soil physical, chemical, and biological properties and processes (Stott 2019). Soil organic C and $\mathrm{N}$ fractions are often the most utilized in soil health assessments. The active fraction of soil organic matter, as measured by soil-test biological activity (via the flush of carbon dioxide $\left[\mathrm{CO}_{2}\right]$ following rewetting of dried soil), can be an important indicator of soil health assessment (Franzluebbers 2016). When assessing inherent soil $\mathrm{N}$ availability in a greenhouse growth bioassay, soil-test biological activity, total soil $\mathrm{N}$, and residual inorganic $\mathrm{N}$ were key indicators on designing agricultural systems to achieve greater ecological integrity to meet global demands of the human population for water, energy, and nutrients, while fostering biodiversity and resilience to climatic change (NRC 2010). Agro-ecological approaches that include less intensive tillage, greater crop diversity, and integration of agricultural enterprises have gained traction in the Soil Health Division of the USDA Natural Resources Conservation Service (NRCS), and promotion of its "Unlock the Secrets in the Soil" campaign. One of these conservation approaches to keep soil covered

Received April 22, 2020; Revised October 6, 2020; Accepted October 12, 2020; Published online April 17, 2021.
Alan J. Franzluebbers is a research ecologist with USDA Agricultural Research Service (ARS) in Raleigh, North Carolina. Stephen W. Broome is soil scientist with North Carolina State University in Raleigh, North Carolina. Katherine L. Pritchett was a graduate research assistant at North Carolina State University in Raleigh, North Carolina. Michael G. Wagger is a retired soil scientist with North Carolina State University in Raleigh, North Carolina. Nathan Lowder is a soil health specialist with USDA Natural Resources Conservation Service (NRCS) in Salisbury, North Carolina. Steve Woodruff is a regional agronomist with USDA NRCS in Greensboro, North Carolina. Michelle Lovejoy is director of North Carolina Foundation for Soil and Water Conservation in Raleigh, North Carolina. 
(Franzluebbers and Pershing 2018). Greater understanding of how soil changes under conservation agricultural management systems will be important for designing systems for long-term sustainability.

Quantifying the effects of multispecies cover cropping on subsequent crop yields and soil properties is needed to verify some of the limited testing of claims for improved soil health. After the third year of multispecies cover cropping in Tennessee, soybean (Glycine max L.) yield was greater than with single-species cover cropping systems and with no cover crop (Chu et al. 2017). Although soil organic C was not affected by type of cover cropping system, anaerobic $\mathrm{N}$ mineralization was greater under multispecies cover cropping than under wheat (Triticum aestivum L.) as cover crop and without cover crop. Following establishment of different single-species and multispecies cover crops in Pennsylvania during two consecutive years, Finney et al. (2017) observed the following: (1) greater microbial biomass under cover cropping systems than without cover cropping, (2) greater arbuscular mycorrhizal fungi under oat (Avena sativa L.) and rye (Secale cereale L.), (3) greater nonarbuscular mycorrhizal fungi under hairy vetch (Vicia villosa Roth), and (4) greater soil microbial activity under cover crops than without cover crop. In a survey of farms in the Mid-Atlantic region of the United States, soil-test biological activity and net $\mathrm{N}$ mineralization were greater on farms that routinely used multispecies cover cropping compared with single-species cover cropping or no cover crop (Franzluebbers 2020). Therefore, there is growing evidence that diversification of agricultural systems with cover cropping results in changes in soil health conditions, and in particular soil biological properties. However, there is relatively little information on biomass production and soil health condition under multispecies cover cropping practiced on farms in the southeastern United States. Our objective in this study was to test in the short term whether farms transitioning to multispecies cover crops as a new management approach might lead to changes in (1) winter cover crop biomass production and (2) soil physical, chemical, and biological properties.

\section{Materials and Methods}

Cover crops were established on $\sim 4$ ha fields of participating farmers in selected Soil and Water Conservation Districts (SWCD) in North Carolina (figure 1), typically using planting and termination equipment already available to each grower. County SWCD districts included Beaufort, Brunswick, Camden, Duplin, Edgecombe, Halifax, Nash, Pitt, and Sampson counties in the Coastal Plain region; Alamance, Davidson, Rowan, Wake, and Stanly counties in the Piedmont region; and Ashe and Henderson counties in the Blue Ridge region (table 1). The project was a combination of research and demonstration, so fields were typically divided into four large field-length strips as treatments (two with multispecies cover crops and two with either single-species cover crop or no cover crop, each with a minimum width of $12 \mathrm{~m}$ ). Multispecies cover crop seed was purchased using project funds and the mix determined based on grower goals, consultation with county SWCD leaders, and general project guidance to include at least four species, including two legumes. Seed was either drilled or broadcast (with 25\% greater seed generally recommended with broadcasting) to meet target dates of seeding by as early as September 15 (broadcast in the Blue Ridge region) or as late as October 31 (no-till drill in Coastal Plain and Piedmont regions). Seed mix, soil type, previous crop, and cover crop management are reported in table 1 for each field. Guidelines for cover crop termination date were set to no earlier than April 15 in the Coastal Plain and Piedmont regions and May 1 in the Blue Ridge region.

Plant biomass production of cover crops was determined in the spring shortly before expected termination or shortly after chemical termination of the cover crop and preparation for summer cash crop $(n=35$ fields total). The predominant method of obtaining biomass yield was by clipping two

\section{Figure 1}

Location of study sites in North Carolina.

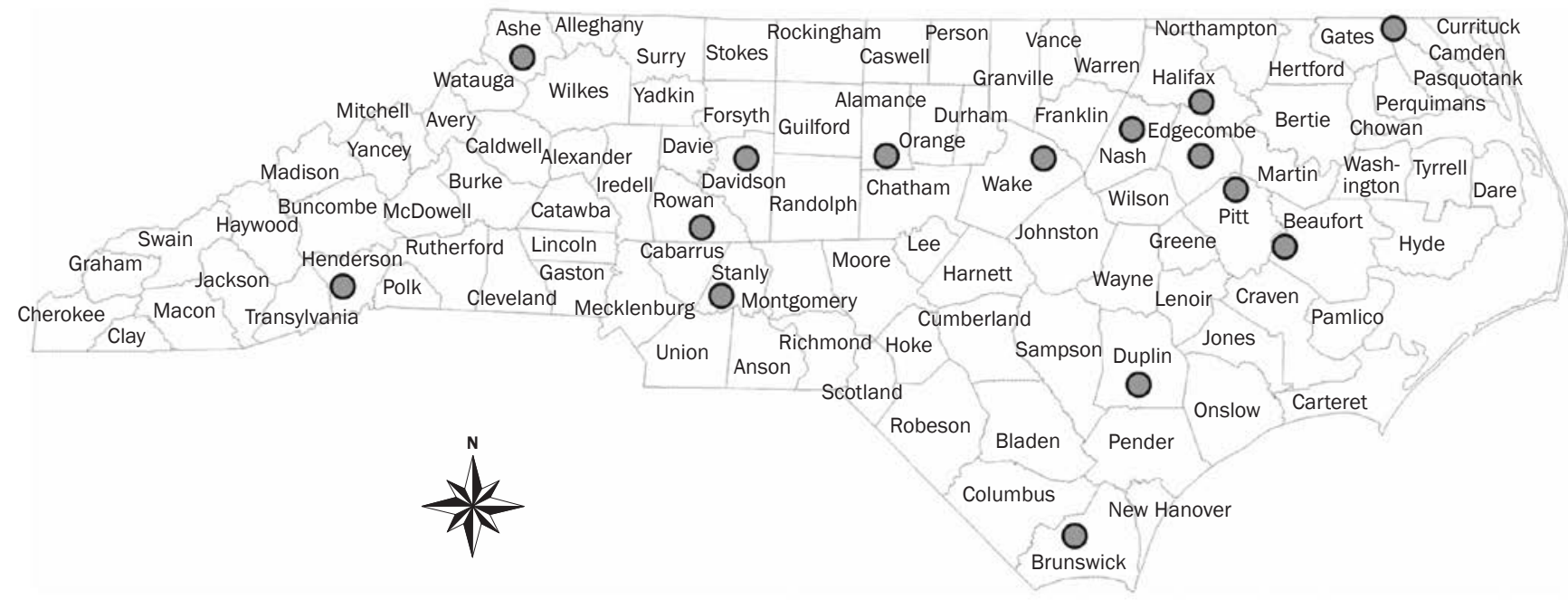


Table 1

Soil and cover crop management characteristics of on-farm demonstration trials in North Carolina (NC) from 2015 to 2019.

\begin{tabular}{|c|c|c|}
\hline NC county & Soil & Management/sampling \\
\hline Alamance & $\begin{array}{l}\text { Cullen clay loam, } 2 \% \text { to } \\
6 \% \text { slope, moderately } \\
\text { eroded (very-fine, } \\
\text { kaolinitic, thermic Typic }\end{array}$ & $\begin{array}{l}2016 \text { to 2017: Corn previous crop, soybean as crop in } 2017 \text {; no-till drilled cover on Oct, } 17,2016 \text {, che- } \\
\text { mically terminated on May 2, } 2017 \text {; four strips total of (1) single-species cover crop (barley), (2) multi- } \\
\text { species cover ( } 35 \mathrm{~kg} \mathrm{ha}^{-1} \text { rye }+8 \mathrm{~kg} \mathrm{ha}^{-1} \text { crimson clover }+8 \mathrm{~kg} \mathrm{ha}^{-1} \text { hairy vetch }+2 \mathrm{~kg} \mathrm{ha}^{-1} \text { tillage rad- } \\
\text { ish); sampled April } 28 \text {. }\end{array}$ \\
\hline
\end{tabular}
Hapludults)

2017 to 2018: Soybean previous crop, corn silage as crop in 2018; no-till drilled cover on Dec. 14, 2017 , chemically terminated on June 15, 2018; four strips total of (1) single-species cover crop (triticale in Rep 1; cereal rye in Rep 2), (2) multispecies cover $\left(35 \mathrm{~kg} \mathrm{ha}^{-1}\right.$ cereal rye $+8 \mathrm{~kg} \mathrm{ha}^{-1}$ crimson clover + $8 \mathrm{~kg} \mathrm{ha}{ }^{-1}$ hairy vetch in Rep 1; $35 \mathrm{~kg} \mathrm{ha}^{-1}$ triticale $+8 \mathrm{~kg} \mathrm{ha}^{-1}$ crimson clover $+8 \mathrm{~kg} \mathrm{ha}^{-1}$ hairy vetch in Rep 2); sampled April 26.

2018 to 2019: Corn silage as previous crop, corn + sorghum as silage crop in 2019; no-till drilled cover on Oct. 22, 2018, organic transition and rolled; four strips total of (1) single-species cover (triticale), (2) multispecies cover (13 kg ha-1 crimson clover $+15 \mathrm{~kg} \mathrm{ha}^{-1}$ Austrian winter pea, $39 \mathrm{~kg} \mathrm{ha}^{-1}$ Cosaque black oat $+45 \mathrm{~kg} \mathrm{ha}^{-1}$ rye); sampled May 6 .

\begin{tabular}{|c|c|c|}
\hline Ashe & $\begin{array}{l}\text { Clifton loam, } 8 \% \text { to } 15 \% \\
\text { slope (fine, mixed, } \\
\text { semiactive, mesic Typic } \\
\text { Hapludults), Evard loam, } \\
15 \% \text { to } 25 \% \text { slope } \\
\text { (fine-loamy, parasesquic, } \\
\text { mesic Typic Hapludults) }\end{array}$ & 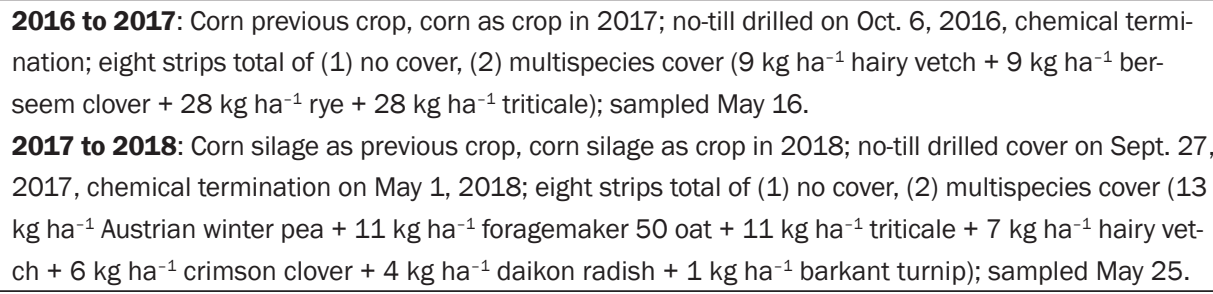 \\
\hline thor & $\begin{array}{l}\text { Rains fine sandy loam, } \\
0 \% \text { to } 2 \% \text { slope (fine- } \\
\text { loamy, siliceous, } \\
\text { semiactive, thermic }\end{array}$ & $\begin{array}{l}2017 \text { to 2018: Corn as previous crop, soybean as crop in 2018; broadcast + minimum-till cover on Oct. } \\
20,2017 \text {, chemical termination on Apr. } 25,2018 ; 12 \text { strips total of (1) no cover, ( } 2 \text { ) multispecies cover } \\
\text { ( } 45 \mathrm{~kg} \mathrm{ha}^{-1} \text { abruzzi rye }+17 \mathrm{~kg} \mathrm{ha}^{-1} \text { Austrian winter pea }+6 \mathrm{~kg} \mathrm{ha}^{-1} \text { crimson clover }+2 \mathrm{~kg} \mathrm{ha}^{-1} \text { tillage } \\
\text { radish); sampled April } 13 .\end{array}$ \\
\hline
\end{tabular}

Typic Paleaquults) 2018 to 2019: Soybean as previous crop, corn as crop in 2019; no-till drilled on Oct. 19, 2018, chemical termination; 12 strips total of (1) no cover, (2) multispecies cover (450 kg ha-1 abruzzi rye $+17 \mathrm{~kg} \mathrm{ha}^{-1}$ Austrian winter pea $+6 \mathrm{~kg} \mathrm{ha}^{-1}$ crimson clover $+2 \mathrm{~kg} \mathrm{ha}^{-1}$ tillage radish); sampled April 16 .

Brunswick Lynchburg fine sandy 2017 to 2018: Corn as previous crop, soybean as crop in 2018; no-till drilled cover on Oct. 4, 2017, loam, $0 \%$ to $2 \%$ slope chemical termination + rolling on May 4, 2018; 22 strips total of (1) no cover, (2) multispecies cover (63 (fine-loamy, siliceous, $\quad$ kg ha- ${ }^{-1}$ rye $+21 \mathrm{~kg} \mathrm{ha}^{-1}$ Austrian winter pea $+7 \mathrm{~kg} \mathrm{ha}^{-1}$ crimson clover $+3 \mathrm{~kg} \mathrm{ha}^{-1} \mathrm{radish}_{\text {); sampled }}$ semiactive, thermic April 12.

Aeric Paleaquults) 2018 to 2019: Soybean as previous crop; no-till drilled, chemical termination; 22 strips total of (1) no cover, (2) multispecies cover $\left(63 \mathrm{~kg} \mathrm{ha}^{-1}\right.$ rye $+21 \mathrm{~kg} \mathrm{ha}^{-1}$ Austrian winter pea $+7 \mathrm{~kg} \mathrm{ha}^{-1}$ crimson clover $+3 \mathrm{~kg} \mathrm{ha}^{-1}$ radish); sampled April 15 .

Camden $\quad$ Bojac loamy sand, 0\% 2017 to 2018: Cotton as previous crop, soybean as crop in 2018; no-till drilled cover on Oct, 14, 2017, to $3 \%$ slope (coarsechemical termination on Apr. 15, 2018; 16 strips total of (1) no cover, (2) multispecies cover (21 kg ha-1 loamy, mixed, semiactive, thermic oat $+18 \mathrm{~kg} \mathrm{ha}^{-1}$ Austrian winter pea $+15 \mathrm{~kg} \mathrm{ha}^{-1}$ crimson clover $+10 \mathrm{~kg} \mathrm{ha}^{-1}$ balansa clover $+3 \mathrm{~kg} \mathrm{ha}^{-1}$ select radish); sampled April 13.

Typic Hapludults)

2018 to 2019: Soybean as previous crop, cotton as crop in 2019; no-till drilled cover on Oct. 15, 2018, chemical termination on Apr. 1, 2019; 12 strips total of (1) no cover, (2) multispecies cover (67 kg ha-1 wheat $+7 \mathrm{~kg} \mathrm{ha}^{-1}$ crimson clover $+10 \mathrm{~kg} \mathrm{ha}^{-1}$ daikon radish $+28 \mathrm{~kg} \mathrm{ha}^{-1}$ Austrian winter pea); sampled April 17.

Davidson Enon fine sandy loam, $2 \%$ to $8 \%$ slope (fine, mixed, active, thermic Ultic Hapludalfs)
2016 to 2017: Corn previous crop, soybean as crop in 2017; no-till drilled cover on Oct. 25, 2016, chemical termination on Apr. 20, 2017; four strips total of (1) single-species cover (rye), (2) multispecies cover (34 kg ha ${ }^{-1}$ rye $+17 \mathrm{~kg} \mathrm{ha}^{-1}$ triticale $+11 \mathrm{~kg} \mathrm{ha}^{-1}$ oat $+11 \mathrm{~kg} \mathrm{ha}^{-1}$ crimson clover $+11 \mathrm{~kg} \mathrm{ha}^{-1}$ hairy vetch $+2 \mathrm{~kg} \mathrm{ha}^{-1}$ daikon radish); sampled April 20 .

2017 to 2018: Soybean as previous crop, corn as crop in 2018; no-till drilled on Oct. 18, 2017, chemical termination; four strips total of (1) single-species cover (rye), (2) multispecies cover ( $7 \mathrm{~kg} \mathrm{ha}^{-1}$ hairy vetch $+7 \mathrm{~kg} \mathrm{ha}^{-1}$ crimson clover $+28 \mathrm{~kg} \mathrm{ha}^{-1}$ triticale $+25 \mathrm{~kg} \mathrm{ha}^{-1}$ black oat $+2 \mathrm{~kg} \mathrm{ha}^{-1}$ rapeseed); sampled May 19. 


\section{Table 1 continued}

\begin{tabular}{|c|c|c|}
\hline NC county & Soil & Management/sampling \\
\hline Duplin & $\begin{array}{l}\text { Johns fine sandy loam, } \\
0 \% \text { to } 2 \% \text { slope (fine- } \\
\text { loamy over sandy or } \\
\text { sandy-skeletal, siliceous, } \\
\text { semiactive, thermic } \\
\text { Aquic Hapludults) }\end{array}$ & $\begin{array}{l}2017 \text { to 2018: Corn as previous crop, corn as crop in 2018; no-till drilled on Oct. 18, 2017, chemical } \\
\text { termination on Apr. 13, 2018; five strips total of (1) no cover, (2) multispecies cover (triticale, Austrian } \\
\text { winter pea, crimson clover, and wheat); sampled April } 12 \text {. } \\
2018 \text { to 2019: Corn as previous crop, corn as crop in } 2019 \text {; no-till drilled on Oct. } 31,2018 \text {, chemical ter- } \\
\text { mination on Apr. } 18,2019 \text {; four strips total of (1) no cover, (2) multispecies cover ( } 110 \mathrm{~kg} \mathrm{ha}^{-1} \text { rye }+3 \mathrm{~kg} \\
\text { ha }^{-1} \text { barkant turnip + } 4 \mathrm{~kg} \mathrm{ha}^{-1} \text { purple-top turnip }+3 \mathrm{~kg} \mathrm{ha}^{-1} \text { hairy vetch }+10 \mathrm{~kg} \mathrm{ha}^{-1} \mathrm{crimson}_{\text {clover); }} \\
\text { sampled April } 16 \text {. }\end{array}$ \\
\hline $\begin{array}{l}\text { Halifax } \\
\text { (east) }\end{array}$ & $\begin{array}{l}\text { Goldsboro fine sandy } \\
\text { loam (fine-loamy, } \\
\text { siliceous, subactive, } \\
\text { thermic Aquic Paleudults) }\end{array}$ & $\begin{array}{l}2015 \text { to 2016: Cotton previous crop, cotton as crop in 2016; no-till drilled cover on Oct. 31, 2015, } \\
\text { chemical termination; three strips total of (1) no cover, (2) multispecies cover ( } 17 \mathrm{~kg} \mathrm{ha}^{-1} \text { Center Seed } \\
\text { Holcomb seed blend }+3 \mathrm{~kg} \mathrm{ha}^{-1} \text { forage collard }+17 \mathrm{~kg} \mathrm{ha}^{-1} \text { Walnut Creek Seeds super soil builder }+3 \\
\mathrm{~kg} \mathrm{ha}^{-1} \text { phacelia); sampled April } 22 \text {. }\end{array}$ \\
\hline $\begin{array}{l}\text { Halifax } \\
\text { (west) }\end{array}$ & $\begin{array}{l}\text { Emporia fine sandy loam } \\
\text { (fine-loamy, siliceous, } \\
\text { subactive, thermic Typic } \\
\text { Hapludults) }\end{array}$ & $\begin{array}{l}2015 \text { to 2016: Soybean previous crop, cotton as crop in 2016; broadcast cover first week of October } \\
\text { of } 2015 \text {, chemical termination; four strips total of (1) no cover, (2) multispecies cover ( } 17 \mathrm{~kg} \mathrm{ha}^{-1} \text { Cen- } \\
\text { ter Seed Holcomb seed blend }+3 \mathrm{~kg} \mathrm{ha}^{-1} \text { forage collard }+17 \mathrm{~kg} \mathrm{ha}^{-1} \text { Walnut Creek Seeds super soil } \\
\text { builder + } 3 \mathrm{~kg} \mathrm{ha}^{-1} \text { phacelia); sampled April } 22 \text {. }\end{array}$ \\
\hline Nash (1) & $\begin{array}{l}\text { Norfolk loamy sand } \\
\text { (fine-loamy, kaolinitic, } \\
\text { thermic Typic } \\
\text { Kandiudults) }\end{array}$ & $\begin{array}{l}2015 \text { to 2016: Soybean previous crop, soybean as crop in 2016; broadcast four strips cover on Oct. } \\
\text { 20, } 2015 \text {, no-till drilled eight strips cover on Dec. 8, 2015, and Jan. 8, 2016, Chemical and disk } \\
\text { termination; } 12 \text { strips total of (1) no cover ( } 3 \text { strips), (2) single-species cover (rye; } 3 \text { strips), (3) multi- } \\
\text { species cover ( } 50 \mathrm{~kg} \mathrm{ha}^{-1} \text { rye }+10 \mathrm{~kg} \mathrm{ha}^{-1} \text { crimson clover }+7 \mathrm{~kg} \mathrm{ha}^{-1} \text { tillage radish }+17 \mathrm{~kg} \mathrm{ha}^{-1} \\
\text { Austrian winter pea }+1 \mathrm{~kg} \text { ha }^{-1} \text { hairy vetch; } 6 \text { strips); sampled April } 24 .\end{array}$ \\
\hline Nash (2) & $\begin{array}{l}\text { Norfolk, Georgeville, and } \\
\text { Faceville soils, } 2 \% \text { to } \\
8 \% \text { slope (fine-loamy, } \\
\text { kaolinitic, thermic } \\
\text { Typic Kandiudults) }\end{array}$ & $\begin{array}{l}2016 \text { to 2017: Field bean as previous crop, vegetables as crop in 2017; no-till drilled late October, disk- } \\
\text { till termination on Apr. 13, 2017; nine strips total of (1) no cover, (2) multispecies cover ( } 45 \mathrm{~kg} \mathrm{ha}^{-1} \text { rye } \\
+11 \mathrm{~kg} \mathrm{ha}^{-1} \text { crimson clover + } 2 \mathrm{~kg} \mathrm{ha}^{-1} \text { daikon radish); sampled April } 3 \text {. }\end{array}$ \\
\hline
\end{tabular}




\section{Table 1 continued}

\begin{tabular}{|c|c|c|}
\hline NC county & Soil & Management/sampling \\
\hline Nash (3) & $\begin{array}{l}\text { Faceville loamy sand, } \\
1 \% \text { to } 6 \% \text { slope (fine, } \\
\text { kaolinitic, thermic Typic } \\
\text { Kandiudults) }\end{array}$ & $\begin{array}{l}2017 \text { to 2018: Sorghum as previous crop, soybean as crop in } 2018 \text {; no-till drilled cover on Oct. } 31 \text {, } \\
2017 \text {, chemical termination; four strips total of (1) single-species cover of rye, (2) multispecies cover ( } 45 \\
\mathrm{~kg} \mathrm{ha}^{-1} \text { rye }+11 \mathrm{~kg} \mathrm{ha}^{-1} \text { crimson clover }+2 \mathrm{~kg} \mathrm{ha}^{-1} \text { daikon radish); sampled April } 25 \text {. } \\
2018 \text { to } 2019 \text { : Soybean as previous crop; no-till drilled on Oct. } 25,2018 \text {, rolled termination; four strips } \\
\text { total of (1) single-species cover (oat), }(2) \text { multispecies cover }\left(20 \mathrm{~kg} \mathrm{ha}^{-1} \text { triticale }+13 \mathrm{~kg} \mathrm{ha}^{-1} \text { Florida } 501\right. \\
\text { oat }+3 \mathrm{~kg} \mathrm{ha}^{-1} \text { trophy rapeseed }+20 \mathrm{~kg} \mathrm{ha}^{-1} \text { rye }+11 \mathrm{~kg} \mathrm{ha}^{-1} \text { Dixie crimson clover); sampled May } 7 .\end{array}$ \\
\hline
\end{tabular}

2017 to 2018: Vegetables as previous crop, vegetables as crop in 2018; no-till drilled cover on Oct. 25, 2017, chemical termination on Apr. 15, 2018; four strips total of (1) single-species cover (crimson clover), (2) multispecies cover ( $6 \mathrm{~kg} \mathrm{ha}^{-1}$ crimson clover $+4 \mathrm{~kg} \mathrm{ha}^{-1}$ hairy vetch $+17 \mathrm{~kg} \mathrm{ha}^{-1}$ Austrian winter pea $+46 \mathrm{~kg} \mathrm{ha}^{-1}$ barley $+1 \mathrm{~kg} \mathrm{ha}^{-1}$ rapeseed); sampled April 11.

\begin{tabular}{ll}
\hline Stanly & Badin channery silt \\
& loam, $2 \%$ to $8 \%$ slope \\
& (fine, mixed, semiactive, \\
& thermic Typic \\
& Hapludults)
\end{tabular}

2015 to 2016: Corn previous crop, cotton as crop in 2016; no-till drilled cover on Oct. 15, 2015, chemical termination May 2, 2016; total of four strips of (1) no cover, (2) multispecies cover (11 kg ha-1 crimson clover $+2 \mathrm{~kg} \mathrm{ha}^{-1}$ radish $+17 \mathrm{~kg} \mathrm{ha}^{-1}$ triticale $+17 \mathrm{~kg} \mathrm{ha}^{-1}$ ryegrass); sampled June 1 . 2016 to 2017: Cotton as previous crop, cotton as crop in 2017; no-till drilled late October, chemical termination Apr. 20, 2017; four strips total of (1) no cover, (2) multispecies cover (6 kg ha-1 crimson clover $+56 \mathrm{~kg} \mathrm{ha}^{-1}$ triticale $+11 \mathrm{~kg} \mathrm{ha}^{-1}$ ryegrass $+17 \mathrm{~kg} \mathrm{ha}^{-1}$ Austrian winter pea); sampled April 18 . 2017 to 2018: Cotton as previous crop, cotton as crop in 2018; no-till drilled Oct. 30, 2017, chemical termination Apr. 15, 2018; four strips total of (1) no cover, (2) multispecies cover (6 kg ha-1 crimson clover $+56 \mathrm{~kg} \mathrm{ha}^{-1}$ triticale $+11 \mathrm{~kg} \mathrm{ha}^{-1}$ ryegrass $+17 \mathrm{~kg} \mathrm{ha}^{-1}$ Austrian winter pea); sampled April 11 . 2018 to 2019: Cotton as previous crop, cotton as crop in 2019; no-till drilled on Oct. 30, 2018, chemical termination; four strips total of (1) no cover, (2) multispecies cover (17 kg ha-1 winter pea $+9 \mathrm{~kg}$ ha ${ }^{-1}$ crimson clover $+17 \mathrm{~kg} \mathrm{ha}^{-1}$ ryegrass $+56 \mathrm{~kg} \mathrm{ha}^{-1}$ triticale); sampled April 29.

Wake Rawlings-Rion complex, $6 \%$ to $10 \%$ slope (fineloamy, mixed, subactive /semiactive, thermic Typic Hapludults), Wedowee-Saw complex, $2 \%$ to $6 \%$ slope (fine, kaolinitic, thermic Typic Kanhapludults)
2016 to 2017: Soybean as previous crop, soybean as crop in 2017; broadcast cover on Oct. 15, 2016, chemical termination Apr. 17, 2017; six strips total of (1) no cover, (2) multispecies cover (27 kg ha-1 ryegrass $+20 \mathrm{~kg} \mathrm{ha}^{-1}$ brooks oat $+7 \mathrm{~kg} \mathrm{ha}^{-1}$ crimson clover $+13 \mathrm{~kg} \mathrm{ha}^{-1}$ Austrian winter pea); sampled April 28.

2017 to 2018: Soybean as previous crop, soybean as crop in 2018; broadcast cover on Oct. 15, 2017, chemical termination Apr. 21, 2018; six strips total of (1) no cover, (2) multispecies cover (27 kg ha-1 ryegrass $+20 \mathrm{~kg} \mathrm{ha}^{-1}$ brooks oat $+7 \mathrm{~kg} \mathrm{ha}^{-1}$ crimson clover $+13 \mathrm{~kg} \mathrm{ha}^{-1}$ Austrian winter pea); sampled April 17.

Notes: Plant species were Austrian winter pea (Pisum sativum), balansa clover (Trifolium michelianum), barley (Hordeum vulgare), berseem clover (Trifolium alexandrinum), collard (Brassica oleraceae), corn (Zea mays), Cosaque black oat (Avena strigosa), cotton (Gossypium hirsutum), crimson clover (Trifolium incarnatum), field bean (Vicia faba), hairy vetch (Vicia villosa), oat (Avena sativa), phacelia (Phacelia tanacetifolia), radish (Raphanus sativus), rapeseed (Brassica napus), rye (Secale cereale), ryegrass (Lolium multiflorum), snap bean (Phaseolus vulgaris), sorghum (Sorghum bicolor), soybean (Glycine max), triticale (x Triticosecale), turnip (Brassica rapa), and wheat (Triticum aestivum).

$0.25 \mathrm{~m}^{2}$ areas in each of six sampling sites of each treatment within a field. This was primarily three sites (separated by $\sim 30 \mathrm{~m}$ ) in each of two replicate strips, although some trials had six or more replicate strips, and therefore, one site was sampled from each strip. Two subsamples per sampling site were separated by $8 \mathrm{~m}$. A metal square 0.5 by 0.5 $\mathrm{m}$ was placed on the ground, and plant biomass $4 \mathrm{~cm}$ from ground level was clipped and placed into a cloth bag. The two subsamples per site were combined. In 2016 (except for the Stanly location, which was sampled as in subsequent years), biomass was collected by rear-bag mower set to $5 \mathrm{~cm}$ height from 
one strip $(0.5$ by $6 \mathrm{~m})$ at each of the six sites of each treatment. Biomass samples were dried in an oven at $50^{\circ} \mathrm{C}$ for $\geq 3$ days until constant mass. Biomass was reported on a dry-matter basis without correction for any potential soil contamination, which was not considered significant. Biomass was initially chopped coarsely, well mixed, and a representative subsample ground in a Wiley mill to pass a $1 \mathrm{~mm}$ screen. Carbon and $\mathrm{N}$ concentrations of harvested cover crop biomass were determined by dry combustion on a Leco TruMac CN analyzer (Leco Corp., St. Joseph, Michigan).

Soil was sampled at the same six sites from where plant biomass was collected in each cover crop treatment of each field $(n=31$ fields total; 4 fields were abandoned prior to soil sampling in 2016). Soil was typically a composite of eight cores (4 cm diameter) separated by $1 \mathrm{~m}$ in a diagonal transect line between the two plant biomass subsample sites at depth of 0 to $5 \mathrm{~cm}$, and a composite of four cores at depth of 5 to $15 \mathrm{~cm}$ at every other location of the surface samples. Soil was collected after lightly brushing away surface residues. Composited cores in a paper bag were dried in an oven at $55^{\circ} \mathrm{C}$ for $\sim 3$ days until constant mass. Soil bulk density was determined from the mass and volume of cores (503 $\mathrm{cm}^{3}$ for both depths).

Following drying, soil was gently crushed to pass a screen with $4.75 \mathrm{~mm}$ openings (4 mesh). Stones and plant residues not passing the screen were removed. Subsamples for total organic $\mathrm{C}$ and $\mathrm{N}$ and residual inorganic $\mathrm{N}$ were ground further to a fine powder in a ball mill. Total organic $\mathrm{C}$ and $\mathrm{N}$ were determined with dry combustion using a Leco TruMac CN analyzer.

Soil organic $\mathrm{C}$ and $\mathrm{N}$ fractions were determined according to methods of Franzluebbers et al. (2018). Briefly, soil microbial biomass C (SMBC) was determined with chloroform fumigation-incubation without subtraction of a control and using an efficiency factor of 0.41 (Voroney and Paul 1984). Soil-test biological activity was determined from the flush of $\mathrm{CO}_{2}$ following rewetting of dried soil $(0$ to $3 \mathrm{~d}$ ) with aerobic incubation of soil at $50 \%$ water-filled pore space and $25^{\circ} \mathrm{C}$. For analyses of SMBC and soil-test biological activity, duplicate $50 \mathrm{~g}$ soil samples in $60 \mathrm{~mL}$ glass jars were wetted and placed in a $0.9 \mathrm{~L}$ canning jar along with a vial containing $10 \mathrm{~mL}$ of 1 $\mathrm{M}$ sodium hydroxide $(\mathrm{NaOH})$ to trap $\mathrm{CO}_{2}$ and a vial of water to maintain humidity.
Alkali traps were replaced at 3 and 10 days of incubation and $\mathrm{CO}_{2}-\mathrm{C}$ determined by titration with $1 \mathrm{M}$ hydrogen chloride $(\mathrm{HCl})$ with vigorous stirring in the presence of barium chloride $\left(\mathrm{BaCl}_{2}\right)$ (that precipitated to form barium carbonate $\left[\mathrm{BaCO}_{3}\right]$ ) to a phenolphthalein endpoint. At 10 days, one of the subsamples was removed from the incubation jar, fumigated with chloroform $\left(\mathrm{CHCl}_{3}\right)$ under vacuum for one day, vapors removed, placed into a separate canning jar along with vials of alkali and water, and incubated at $25^{\circ} \mathrm{C}$ for a further 10 days (SMBC). Basal soil respiration (BSR) was determined from the assumed linear rate of $\mathrm{C}$ mineralization from 10 to 24 days of incubation. Potential C mineralization was calculated from the cumulative evolution of $\mathrm{CO}_{2}$ during 24 days of incubation. Mineralizable $\mathrm{N}$ was determined from the difference in inorganic $\mathrm{N}$ concentration between 0 and 24 days of incubation. Inorganic $\mathrm{N}$ (ammonium- $\mathrm{N}+$ nitrite- $\mathrm{N}+$ nitrate- $\left.\mathrm{N}\left[\mathrm{NH}_{4}-\mathrm{N}+\mathrm{NO}_{2}-\mathrm{N}+\mathrm{NO}_{3}-\mathrm{N}\right]\right)$ was determined from the filtered extract of a $10 \mathrm{~g}$ subsample of dried $\left(55^{\circ} \mathrm{C}\right.$ for three days) and sieved (10 mesh [2 mm]) soil that was shaken with $20 \mathrm{~mL}$ of $2 M$ potassium chloride $(\mathrm{KCl})$ for 30 minutes using salicylate-nitroprusside and hydrazine autoanalyzer techniques (Bundy and Meisinger 1994). Sand, clay, and particulate organic C and N concentrations were predicted from ballmilled subsamples scanned by near-infrared spectroscopy that was calibrated to a library of laboratory-determined values (Deiss et al. 2017) specific to similar types of soils in the current study. Sand was calibrated to mass collected on a $270-$ mesh screen $(0.053 \mathrm{~mm}$ openings). Clay was calibrated to hydrometer values after 5 hours of settling. Particulate organic $\mathrm{C}$ and $\mathrm{N}$ were calibrated to concentrations following sieving for the sand fraction. Routine soil nutrient analyses were conducted by Soil Testing Services of the North Carolina Department of Agriculture and Consumer Services in Raleigh North Carolina. Analysis of phosphorus (P), potassium $(\mathrm{K})$, calcium $(\mathrm{Ca})$, magnesium $(\mathrm{Mg})$, sulfur $(\mathrm{S})$, sodium $(\mathrm{Na})$, manganese $(\mathrm{Mn})$, copper $(\mathrm{Cu})$, and zinc $(\mathrm{Zn})$ was with argon plasma emission spectroscopy from a $25 \mathrm{~mL}$ Mehlich-3 extract of a $2.5 \mathrm{~mL}$ scoop of soil (Mehlich 1984a). Soil weight of a $10 \mathrm{~mL}$ scoop of soil was used to calculate sieved soil density. Soil $\mathrm{pH}$ was in $1: 1$ soil to 0.01 mol $\mathrm{L}^{-1} \mathrm{CaCl}_{2}$ and reported as a water $\mathrm{pH}$ by addition of $0.6 \mathrm{pH}$ units. Humic matter was from $\mathrm{NaOH}$ digestion and colorimetric determination (Mehlich 1984b).

Plant biomass was analyzed with the general linear model procedure of SAS v. 9.4 as a completely randomized design for each trial. Across-location analysis of biomass was conducted from treatment means from each field as input data. Soil properties were analyzed across sites only with the general linear model using mean properties across field replications of each trial. Correlations of soil and plant variables across depths and field locations were conducted. Significant differences were declared at $p \leq 0.05$. Trends were considered at $p \leq 0.10$.

\section{Results and Discussion}

Cover Crop Biomass and Carbon and Nitrogen Accumulation. Cover crop biomass accumulation was significantly greater $(p \leq$ $0.05)$ with multispecies cover cropping than without cover cropping in 21 of 24 locations (table 2). This significant effect was expected, since growth in the multispecies cover crop treatment was intentional and growth in the no cover crop treatment was naturally occurring. At one location, the effect was only a trend and at two locations, biomass was the same between multispecies cover cropping and overwintering/spring weed growth. Out of 13 comparisons, multispecies cover cropping had significantly greater biomass than single-species cover cropping at only one location, whereas a trend for greater biomass occurred at three locations and no difference was observed at nine locations. At no location did multispecies cover cropping yield significantly less than single-species cover cropping.

Biomass $\mathrm{N}$ accumulation had similar treatment effects, i.e., greater biomass $\mathrm{N}$ accumulation occurred with multispecies cover cropping than without cover crop in 20 of 24 locations and no difference between systems in the remaining four locations (table 2). Biomass $\mathrm{N}$ accumulation was significantly greater in multispecies cover cropping than in single-species cover cropping in three of 13 comparisons. Inclusion of legumes into the cover crop mixes helped to bolster $\mathrm{N}$ accumulation.

Cover crop biomass $\mathrm{C}: \mathrm{N}$ ratio was highly variable between treatments across locations (table 2). Compared with winter weed growth when no cover crop was planted, multispecies cover cropping had greater $\mathrm{C}: \mathrm{N}$ ratio at nine locations and a trend for greater $\mathrm{C}: \mathrm{N}$ ratio at one additional location. 
Table 2

Biomass dry matter, nitrogen $(\mathrm{N})$ content, and carbon $(\mathrm{C}): \mathrm{N}$ ratio of cover crop treatments (no cover crop [None]; single-species cover crop [SSCC]; multispecies cover crop [MSCC]) at each location.

\begin{tabular}{|c|c|c|c|c|c|c|c|c|c|c|c|c|c|}
\hline \multirow[b]{2}{*}{ County } & \multirow[b]{2}{*}{ Year } & \multicolumn{4}{|c|}{ Biomass (kg ha-1) } & \multicolumn{4}{|c|}{ Biomass $\mathrm{N}\left(\mathrm{kg} \mathrm{ha}^{-1}\right)$} & \multicolumn{4}{|c|}{ Biomass C:N ratio } \\
\hline & & None & sscc & MScc & $\begin{array}{l}\text { Signif- } \\
\text { icance }\end{array}$ & None & sscc & MScc & $\begin{array}{l}\text { Signif- } \\
\text { icance }\end{array}$ & None & sscc & MScc & $\begin{array}{l}\text { Signif- } \\
\text { icance }\end{array}$ \\
\hline \multicolumn{14}{|l|}{ Coastal Plain } \\
\hline \multirow[t]{2}{*}{ Beaufort } & 2018 & 192 & ND & 697 & $* * *$ & 2 & ND & 10 & $* * *$ & 32 & ND & 31 & NS \\
\hline & 2019 & 0 & ND & 917 & $* * *$ & 0 & ND & 21 & NS & ND & ND & 19 & \\
\hline \multirow[t]{2}{*}{ Brunswick } & 2018 & 525 & ND & 3,081 & $* * *$ & 9 & ND & 52 & $* * *$ & 26 & ND & 28 & NS \\
\hline & 2019 & 1,120 & ND & 6,050 & $* * *$ & 20 & ND & 164 & $* * *$ & 25 & ND & 16 & $* * *$ \\
\hline \multirow[t]{2}{*}{ Camden } & 2018 & 349 & ND & 1,280 & $\dagger$ & 6 & ND & 36 & NS & 28 & ND & 18 & * \\
\hline & 2019 & 71 & ND & 1,688 & ** & 1 & ND & 35 & ** & 23 & ND & 22 & NS \\
\hline \multirow[t]{2}{*}{ Duplin } & 2018 & 741 & ND & 2,872 & * & 16 & ND & 50 & * & 20 & ND & 25 & NS \\
\hline & 2019 & 732 & ND & 3,795 & $\star *$ & 12 & ND & 44 & $* *$ & 24 & ND & 40 & * \\
\hline Edgecombe & 2016 & ND & 999 & 1,728 & $\dagger$ & ND & 16 & 22 & NS & ND & 27 & 30 & $\dagger$ \\
\hline Halifax (E) & 2016 & 327 & ND & 662 & $* *$ & 6 & ND & 12 & $* *$ & 23 & ND & 21 & NS \\
\hline Halifax (W) & 2016 & ND & ND & 1,039 & & ND & ND & 18 & & ND & ND & 26 & \\
\hline Nash (1) & 2016 & 1,263 & 1,690 & 1,275 & NS & 18 & 22 & 19 & NS & 33 & 36 & 29 & NS \\
\hline Nash (2) & 2016 & 297 & 1,278 & 1,241 & $* *$ & 8 & 15 & 19 & * & 22 & 44 & 30 & * \\
\hline Nash (3) & 2016 & 594 & 512 & 713 & NS & 7 & 8 & 10 & NS & 32 & 24 & 27 & $\dagger$ \\
\hline Nash & 2017 & 654 & ND & 1,320 & $* *$ & 11 & ND & 19 & * & 25 & ND & 31 & ** \\
\hline Nash & 2018 & ND & 740 & 1,093 & $\dagger$ & ND & 9 & 18 & * & ND & 32 & 29 & NS \\
\hline Nash & 2019 & ND & 3,698 & 3,782 & NS & ND & 49 & 64 & * & ND & 34 & 26 & * \\
\hline Pitt & 2016 & 728 & ND & 1,268 & * & 9 & ND & 16 & * & 34 & ND & 35 & NS \\
\hline \multicolumn{14}{|l|}{ Piedmont } \\
\hline \multirow[t]{3}{*}{ Alamance } & 2017 & ND & 10,700 & 10,233 & NS & ND & 157 & 166 & NS & ND & 30 & 27 & $\dagger$ \\
\hline & 2018 & ND & 5,680 & 4,022 & NS & ND & 104 & 88 & NS & ND & 24 & 20 & NS \\
\hline & 2019 & ND & 9,748 & 9,185 & NS & ND & 99 & 104 & NS & ND & 44 & 42 & NS \\
\hline \multirow[t]{2}{*}{ Davidson } & 2017 & ND & 1,894 & 1,728 & NS & ND & 27 & 26 & NS & ND & 31 & 31 & NS \\
\hline & 2018 & ND & 4,243 & 4,917 & * & ND & 36 & 116 & $* * *$ & ND & 55 & 19 & $* * *$ \\
\hline \multirow[t]{2}{*}{ Rowan } & 2017 & ND & 1,477 & 1,805 & $\dagger$ & ND & 38 & 34 & NS & ND & 15 & 22 & $* * *$ \\
\hline & 2018 & ND & 1,714 & 1,780 & NS & ND & 59 & 44 & NS & ND & 13 & 18 & $\star *$ \\
\hline \multirow[t]{4}{*}{ Stanly } & 2016 & 1,948 & ND & 7,149 & $* * *$ & 18 & ND & 111 & $* *$ & 32 & ND & 30 & NS \\
\hline & 2017 & 1,845 & ND & 2,472 & $* *$ & 29 & ND & 54 & $* *$ & 28 & ND & 21 & $* * *$ \\
\hline & 2018 & 3,515 & ND & 4,491 & $* *$ & 72 & ND & 100 & $* *$ & 22 & ND & 20 & NS \\
\hline & 2019 & 2,202 & ND & 8,884 & $* * *$ & 39 & ND & 118 & $* *$ & 23 & ND & 34 & $* *$ \\
\hline \multirow[t]{2}{*}{ Wake } & 2017 & 300 & ND & 900 & $* * *$ & 7 & ND & 11 & * & 21 & ND & 35 & * \\
\hline & 2018 & 291 & ND & 466 & * & 6 & ND & 10 & * & 24 & ND & 20 & $\dagger$ \\
\hline \multicolumn{14}{|l|}{ Blue Ridge } \\
\hline \multirow[t]{2}{*}{ Ashe } & 2017 & 533 & ND & 5,333 & $* * *$ & 10 & ND & 83 & $* * *$ & 22 & ND & 29 & * \\
\hline & 2018 & 952 & ND & 4,196 & $* * *$ & 21 & ND & 72 & $* * *$ & 18 & ND & 26 & $* *$ \\
\hline \multirow[t]{2}{*}{ Henderson } & 2017 & 2,800 & ND & 10,267 & $* * *$ & 52 & ND & 109 & $* * *$ & 24 & ND & 45 & $* *$ \\
\hline & 2018 & 169 & ND & 2,633 & * & 4 & ND & 41 & * & 15 & ND & 27 & $* *$ \\
\hline
\end{tabular}

$\dagger, *, * *$, and $* * *$ indicate significance between means at $p \leq 0.10, p \leq 0.05, p \leq 0.01$, and $p \leq 0.001$, respectively. NS is not significant.

This contrasted with lower C:N ratio than winter weed growth at three locations and a trend for lower C:N ratio at two additional locations. Nine locations had no significant difference in biomass $\mathrm{C}: \mathrm{N}$ ratio between winter weed growth and multispecies cover cropping. Greater C:N ratio of multispecies cover crops than winter weeds was likely a function of plant growth stage, in which larger and more robust cover crops became progressively more diluted with $\mathrm{N}$ following rapidly expanding spring growth toward maturity (Lemaire et al. 2008).

Compared with single-species cover cropping, biomass $\mathrm{C}: \mathrm{N}$ ratio was significantly lower with multispecies cover cropping at two locations and a trend for lower at an additional location (table 2). However, biomass C:N ratio was significantly greater with multispecies than with single-species cover cropping at three locations and a trend for greater at an additional location. A total of six locations had no difference in $\mathrm{C}: \mathrm{N}$ ratio between multispecies and single-species 
cover cropping. Multispecies cover cropping was expected to have lower $\mathrm{C}: \mathrm{N}$ ratio than single-species cover cropping due to inclusion of legumes in the mixture. The two locations in which biomass $\mathrm{C}: \mathrm{N}$ ratio was greater with multispecies than with single-species cover cropping were due to crimson clover (Trifolium incarnatum) as the single species (Rowan County in 2017 and 2018). Therefore, most of the differences in biomass $\mathrm{C}: \mathrm{N}$ ratio were indeed lower with multispecies cover cropping whenever the single-species cover crop was a nonlegume.

Across locations, winter biomass production was greater with either single-species $\left(3,100 \mathrm{~kg} \mathrm{ha}^{-1}\right)$ or multispecies $(3,285 \mathrm{~kg}$ $\mathrm{ha}^{-1}$ ) cover crops than without cover crop $\left(1,184 \mathrm{~kg} \mathrm{ha}^{-1}\right)$. Winter cover crop biomass production was not different between single- and multispecies cover crops. Similarly, biomass $\mathrm{C}$ and $\mathrm{N}$ contents were greater with cover crops than without, but not different between single- and multispecies cover crops (figure 2). Greater distance between the $90^{\text {th }}$ and $50^{\text {th }}$ percentile compared with the $10^{\text {th }}$ and $50^{\text {th }}$ percentile for both biomass $\mathrm{C}$ and $\mathrm{N}$ contents showed the strongly skewed distribution with occasional high biomass production under favorable environmental conditions, but with typically lower biomass production in the majority of sites. Biomass $\mathrm{C}: \mathrm{N}$ ratio tended to be lower with multispecies cover cropping than with single-species cover cropping $(p=0.10)$. If data from the single-species crimson clover cover crop in the Rowan County locations were removed, leaving only grasses as single-species cover crop as more typical for the region, then $\mathrm{C}: \mathrm{N}$ ratio was 27 with multispecies cover crop and 34 with single-species cover crop $(p=0.03)$.

Looking at the statistical distribution of multispecies cover crop biomass, 33\% of trials produced $<1,292 \mathrm{~kg} \mathrm{ha}^{-1}, 33 \%$ of trials produced 1,292 to $3,790 \mathrm{~kg} \mathrm{ha}^{-1}$, and $33 \%$ of trials produced $>3,790 \mathrm{~kg} \mathrm{ha}^{-1}$. Therefore, a third of the trials were considered deficient in biomass production, since on average this was the biomass production across all trials without a cover crop, i.e., from growth of overwintering/springtime weeds. We used winter weed biomass as a threshold for cover crop success. A combination of factors could have contributed to this low production in some trials, including weather conditions, late planting, persistent herbicide chemicals present, seed dormancy, or late germination for various reasons. A variety of conditions can lead to poor performance, but those growers that want to improve cover crop biomass production will try again and make adjustments. Overcoming the challenges of successful multispecies cover crop establishment through a network approach was the aim of the demonstration portion of this project.

The middle third of trials had 1,292 to $3,790 \mathrm{~kg} \mathrm{ha}^{-1}$ of biomass production, and this was considered reasonably successful. The upper third of trials with $>3,790 \mathrm{~kg} \mathrm{ha}^{-1}$ were considered highly successful. Such high biomass levels contribute to reasonable soil erosion control, good organic C sourcing for soil organisms, and potential to immobilize nutrients for effective nutrient cycling to the succeeding summer cash crop (Snapp et al.

\section{Figure 2}

Statistical distribution of plant biomass (a) carbon (C) content, (b) nitrogen $(\mathrm{N})$ content, and (c) C:N ratio as affected by winter cover crop treatment across 35 field trials in North Carolina. Boxes represent middle $50 \%$ of observations, line in middle of box is median, and error bars represent $10^{\text {th }}$ and $90^{\text {th }}$ percentile limits. Cover crop treatments are no cover crop planted, weeds only (None), single-species cover crop (SSCC), and multispecies cover crop (MSCC). See table 1 for plant species details for each individual trial.

(a)

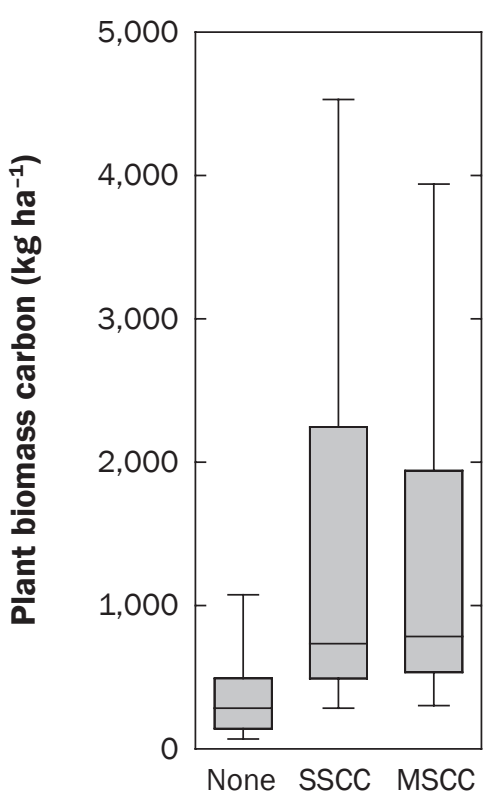

(b)

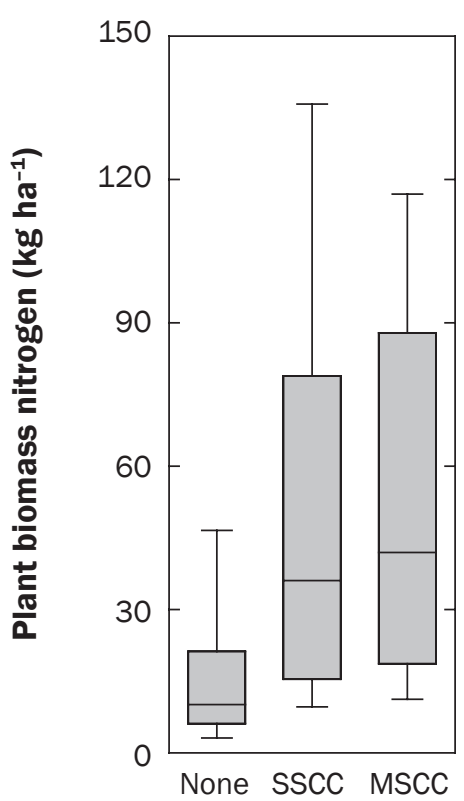

(c)

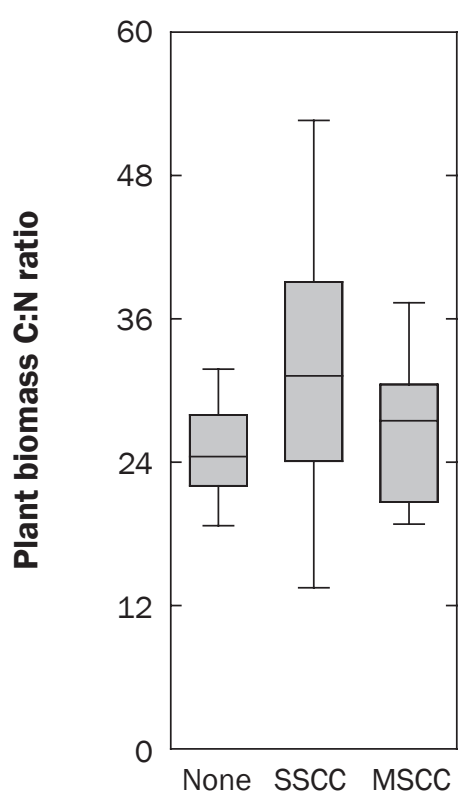

Winter cover crop treatment

Winter cover crop treatment 
2005; Hunter et al. 2019). However, diversity of cover crops alone may not always confer greater ecosystem services than single-species cover crops (Smith et al. 2014). Therefore, how cover crops affect soil properties should be an active area of investigation to gain better understanding of their role in sustainable agricultural development.

Soil Physical Responses. Several soil physical, chemical, and biological properties were measured to identify potential key indicators of soil health improvement with short-term deployment of multispecies cover crops on cropland. Of the physical soil properties, soil bulk density in the field was greater with multispecies cover cropping than without cover crop at 5 to $15 \mathrm{~cm}$ depth, but not at 0 to $5 \mathrm{~cm}$ depth (table 3 ). However, density of soil in the lab after sieving was lower with multispecies than with single-species cover cropping at 5 to $15 \mathrm{~cm}$ depth. Lower field density and sieved density in the 0 to $5 \mathrm{~cm}$ depth compared with the 5 to $15 \mathrm{~cm}$ depth was expected in fields that were primarily under conservation tillage for a year to more than a decade. Lower bulk density in the surface few centimeters of soil compared with deeper depth has been reported previously in conservation agricultural systems (Franzluebbers et al. 1999). This is a natural consequence of surface residues that "mellow" soil from the activity of soil organisms working on $\mathrm{C}$ substrates, but that can leave soil below this interface relatively firm and with greater density due to equipment traffic, lack of soil disturbance at this depth, and only shallow frost heaving. We measured surface residue $\mathrm{C}$ and $\mathrm{N}$ contents in the 2016 trials and found 1,900 $\pm 917 \mathrm{~kg} \mathrm{C} \mathrm{ha}{ }^{-1}$ and $63 \pm$ $26 \mathrm{~kg} \mathrm{~N} \mathrm{ha}^{-1}$ among the four trials. Surface residues provide an organic buffer to protect soil and to feed soil organisms continuously, not only during the cover crop growth period. Slightly lower sand and greater clay concentrations with multispecies cover cropping than with single-species cover cropping in the 0 to $5 \mathrm{~cm}$ depth suggests a small bias in this comparison of other soil chemical and biological properties. However, across the diversity of trial locations, soil texture was relatively uniform with respect to management and soil depth effects.

Soil Chemical Responses. Mehlich-IIIextractable $\mathrm{P}$ and $\mathrm{K}$ were the most affected soil chemical properties (table 3 ). Both soil $\mathrm{P}$ and $\mathrm{K}$ were lower with multispecies cover cropping than without cover crop at depths of 0 to 5 and 5 to $15 \mathrm{~cm}$. Extractable $S$ was also lower with multispecies cover cropping than without cover crop at depth of 5 to $15 \mathrm{~cm}$. There was a trend for lower humic matter with multispecies cover cropping than without cover crop at both depths. Other trends were for greater residual soil ammonium $\left(\mathrm{NH}_{4}\right)$ with multispecies cover cropping than without cover crop at depth of 0 to $5 \mathrm{~cm}$ and greater extractable $\mathrm{Mg}$ and $\mathrm{Mn}$ with multispecies than with single-species cover cropping at depth of 5 to $15 \mathrm{~cm}$. We could not explain these chemical changes in soil properties with the same logic. Lower $\mathrm{P}, \mathrm{K}$, and $\mathrm{S}$ with multispecies cover cropping than without cover crop might have been due to greater plant uptake and/or biological transformation due to root-induced soluble organic C compounds interacting with chemical species and microbial activity. In a long-term field study in Tennessee, vetch cover cropping led to lower extractable P and $\mathrm{K}$ levels in soil compared with no cover cropping, and these chemical changes were also associated with enhanced microbial biomass and altered microbial community structure (Mbuthia et al. 2015). Such studies point to the need for better understanding of how biological interactions in soil can affect soil chemical changes that may or may not affect plant growth, due potentially with interactions from mycorrhizae. Soluble C interactions could also explain the greater $\mathrm{Mg}$ and $\mathrm{Mn}$ concentrations with multispecies cover cropping. The lower humic matter with multiple-species cover cropping than without cover crop remains perplexing, as we did not expect short-term changes in solution chemistry to alter this stabilized fraction of organic matter characterized by humic acids. Although unlikely that multispecies cover crops have such a large effect, research has shown that humic substances can be rapidly mineralized with high microbial activity (Filip and Tesarova 2005).

Soil Biological Responses. Cumulative C mineralization and soil-test biological activity were especially affected by cover crop management (table 3). Both properties were $\sim 10 \%$ greater with multispecies cover cropping than without cover crop at depth of 0 to $5 \mathrm{~cm}$. Both properties were also trending greater with multispecies than with single-species cover cropping at this depth. At depth of 5 to $15 \mathrm{~cm}$, cumulative $\mathrm{C}$ mineralization was greater with multispecies cover cropping than without cover crop and soil- test biological activity was trending greater in this same comparison. In addition, SMBC and basal soil respiration had greater concentrations under multispecies cover cropping than without cover crop at depth of 0 to $5 \mathrm{~cm}$. Net $\mathrm{N}$ mineralization was greater under multispecies than single-species cover cropping at depth of 5 to $15 \mathrm{~cm}$, and was trending greater with multispecies cover cropping than without cover crop at this depth. Particulate organic $\mathrm{C}$ and $\mathrm{N}$ were also greater under multispecies cover cropping than without cover crop at a depth of 0 to 5 $\mathrm{cm}$. Particulate organic $\mathrm{C}$ was greater under multispecies than single-species cover cropping at a depth of 5 to $15 \mathrm{~cm}$. Total soil $\mathrm{N}$ was greater with multispecies cover cropping than without cover crop at depth of 5 to 15 $\mathrm{cm}$ and was trending greater at depth of 0 to $5 \mathrm{~cm}$. However, total organic $\mathrm{C}$ was not different between management systems. Greater concentration of several soil biological properties with multispecies cover cropping than without cover cropping provided ample evidence that short-term changes in soil health attributes can be achieved with multispecies cover cropping. During the first year of multispecies cover cropping, roots of those cover crops were the most likely contributor to particulate organic $\mathrm{C}$ and $\mathrm{N}$ and other changes in soil $\mathrm{C}$ and $\mathrm{N}$ fractions. However, microclimatic changes in surface soil moisture, temperature, and/or solar incidence may have also had an impact. During second and subsequent years of multispecies cover cropping, these same factors, as well as surface deposition of $\mathrm{C}$ - and $\mathrm{N}$-containing cover crop residues, could have influenced soil properties. Long-term changes in soil biological properties have been observed in cropping systems with and without cover crops (Sainju et al. 2007; Mbuthia et al. 2015; Mitchell et al. 2017).

Greater soil-test biological activity, microbial biomass, and particulate organic $\mathrm{C}$ and $\mathrm{N}$ under multispecies cover cropping than without cover crop might further explain the reduction in sieved density of soil, as well as possibly lower extractable $\mathrm{P}, \mathrm{K}$, and $\mathrm{S}$ due to microbial interactions with soil chemical constituents. Bioavailability of chemical constituents as a result of microbial interactions with diverse cropping systems having multispecies cover cropping may be important, and this area of research deserves further attention. Significant changes in soil microbial community structure have been 
Table 3

Soil physical, chemical, and biological properties of soil as affected by cover crop treatments (no cover crop [None]; single-species cover crop [SSCC]; multispecies cover crop [MSCC]) across locations $(n=31)$ and statistical distribution of soil properties across all locations, treatments, depths, and replications $(n=736)$.

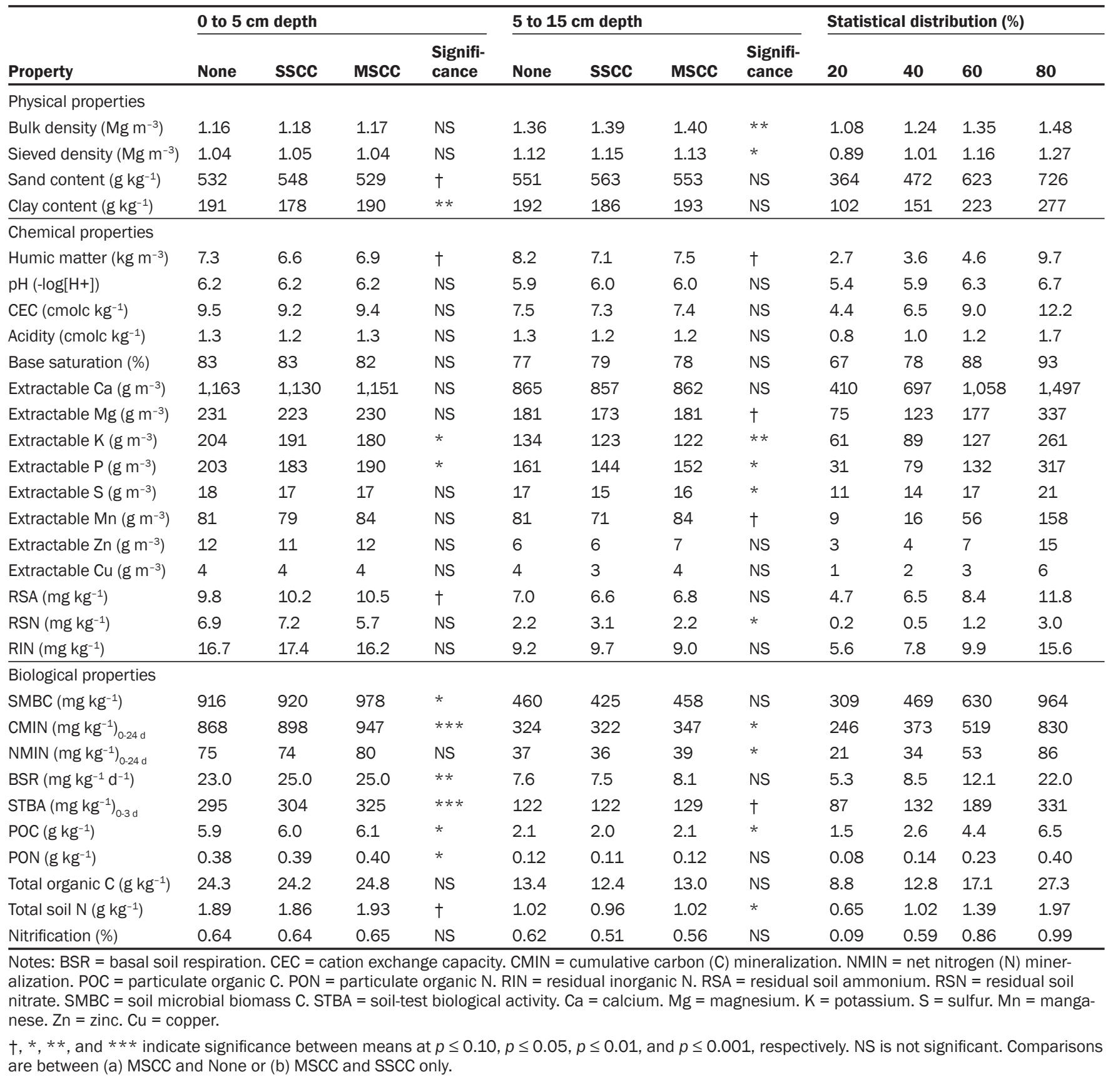

observed in a variety of cover cropping systems in Pennsylvania, particularly with and without legumes (Finney et al. 2017). These microbial community differences could have potentially altered nutrient cycling dynamics - not just of the dominant influence on $\mathrm{N}$ cycling, but also on other nutrients.

Statistical Distribution of Soil Properties. With the collection of soil properties across
15 fields in 13 counties and over one to four years, we amassed a large data set $(n=741)$ with a large range of concentrations due to different soil types, soil depths, and historical management (table 3). These data arguably can be considered a reasonable representation of surface-soil characteristics under agricultural production in North Carolina, which has a total of 100 counties. Concentration of organic matter in the surface 0 to $5 \mathrm{~cm}$ depth will have elevated concentrations relative to a typical 0 to $15 \mathrm{~cm}$ sampling depth, but this bias helped inform upper limits that need to be stretched to achieve better soil health. Mehlich-III-extractable $\mathrm{K}$ in North Carolina has nutrient sufficiency categories set as very low $\left(<20 \mathrm{~g} \mathrm{~m}^{-3}\right)$, low (20 to 50 $\mathrm{g} \mathrm{m}^{-3}$ ), medium (50 to $98 \mathrm{~g} \mathrm{~m}^{-3}$ ), high (98 
to $\left.196 \mathrm{~g} \mathrm{~m}^{-3}\right)$, and very high $\left(>196 \mathrm{~g} \mathrm{~m}^{-3}\right)$ (Hardy et al. 2014). These limits were based on calibration to field crop requirements, and therefore, represent a useful standard. Statistical distribution of soil properties in table 3 was categorized into $20 \%$ sections, i.e., $<20 \%$ represented a very low category, $20 \%$ to $40 \%$ a low category, $40 \%$ to $60 \%$ a medium category, $60 \%$ to $80 \%$ a high category, and $>80 \%$ a very high category. As a direct comparison with the $\mathrm{K}$ sufficiency categories (Hardy et al. 2014), extractable K in this study was very low at $<61 \mathrm{~g} \mathrm{~m}^{-3}$, low at 61 to $89 \mathrm{~g} \mathrm{~m}^{-3}$, medium at 89 to $127 \mathrm{~g} \mathrm{~m}^{-3}$, high at 127 to $261 \mathrm{~g} \mathrm{~m}^{-3}$, and very high at $>261 \mathrm{~g} \mathrm{~m}^{-3}$ (table 3). Statistical distribution in our study tended to shift limits to a greater soil-test $\mathrm{K}$ level than the $\mathrm{K}$ sufficiency categories. However, the correspondence was reasonably good. For soil properties like bulk density, sieved density, or acidity, in which greater values can limit plant growth, the very low category $(<20 \%)$ is a desirable target rather than the very high category $(>80 \%)$.

This statistical approach of soil property categorization across a diversity of soils throughout the state is particularly useful for many of the soil biological properties because they have not been previously characterized so extensively with a common methodology across studies. Therefore, a useful target of basal soil respiration in agricultural soil was $>22.0 \mathrm{mg} \mathrm{kg}^{-1} \mathrm{~d}^{-1}$ at a very high level, but 12.1 to $22.0 \mathrm{mg} \mathrm{kg}^{-1} \mathrm{~d}^{-1}$ was considered high (table 3). SMBC that approaches $900 \mathrm{mg} \mathrm{kg}^{-1}$ (upper limit of high category) at a depth of 0 to $15 \mathrm{~cm}$ would be considered to have much greater soil health condition than a soil with microbial biomass $\mathrm{C}$ of only $300 \mathrm{mg} \mathrm{kg} \mathrm{kg}^{-1}$ (very low category). Statistical distribution of soil properties should only be considered a first estimate of defining soil health conditions. These data do not replace the need to conduct soil-health sufficiency trials across a diversity of soil and management conditions throughout the state.

Similarly, soil-test biological activity as a simple and rapid indicator of soil health might be considered high with a value of 250 $\mathrm{mg} \mathrm{kg} \mathrm{kg}^{-1} 3 \mathrm{~d}^{-1}$, medium with a value of 150 mg kg-1 $3 \mathrm{~d}^{-1}$, and very low with a value of $50 \mathrm{mg} \mathrm{kg}^{-1} 3 \mathrm{~d}^{-1}$ (table 3). To substantiate this approach, soil-test biological activity was in fact calibrated with $\mathrm{N}$ requirement of corn (Zea mays L.) across a diversity of farms in North Carolina and surrounding states (Franzluebbers $2018 \mathrm{~b}, 2020)$. The value of $50 \mathrm{mg} \mathrm{kg}^{-1} 3 \mathrm{~d}^{-1}$ translates to $\mathrm{N}$ requirement of $27.2 \mathrm{~kg} \mathrm{~N} \mathrm{Mg}^{-1}$ grain of expected corn production, and values of 150 and $250 \mathrm{mg} \mathrm{kg}^{-1} 3 \mathrm{~d}^{-1}$ translates to $\mathrm{N}$ requirement of 22.8 and $18.4 \mathrm{~kg} \mathrm{~N} \mathrm{Mg}^{-1}$ grain, respectively (Franzluebbers 2020). If soil-test biological activity were improved to $450 \mathrm{mg} \mathrm{kg}^{-1} 3 \mathrm{~d}^{-1}$, then $\mathrm{N}$ requirement of corn was shifted downward to as low as 9.6 $\mathrm{kg} \mathrm{N} \mathrm{Mg}{ }^{-1}$ grain of expected production. Therefore, this analysis shows that improving soil health conditions leads to greater nutrient resource efficiency, and thereby, a more sustainable agricultural approach to $\mathrm{N}$ management. Opportunities exist and need to be pursued in calibrating these and other soil health indicators to agronomic, environmental, ecological, and social outcomes.

Correlations among Soil Properties. Of the 30 soil properties measured in this study (table 3), many of them had significant correlation with a range of other properties measured, and so were not mutually exclusive. With $>700$ observations for each soil property, many correlations were highly significant. In one approach, we selected correlation coefficients with $|r|>0.7$ as most significant. This significance threshold revealed that total soil $\mathrm{N}$ (12), total organic C (11), soil-test biological activity (10), cumulative $\mathrm{C}$ mineralization (8), net $\mathrm{N}$ mineralization (8), residual soil $\mathrm{NH}_{4}(8)$, and sieved density (8) had the highest number of significant associations with other soil properties.Values in parentheses are the number of most significant associations (i.e., $|r|>0.7)$ with other soil properties, and primarily with those listed here. Another approach was to sum the squares of correlation coefficients among the 30 soil properties to weight all soil properties equally. This yielded the top-associated soil properties of total soil N (11.5), soil-test biological activity (11.1), cumulative C mineralization (10.1), cation exchange capacity (9.9), extractable $\mathrm{Ca}(9.9)$, total organic $\mathrm{C}(9.8)$, net $\mathrm{N}$ mineralization (9.6), and SMBC (9.5). Many of the same soil properties appeared in the top tier of both approaches. Soil properties with the lowest ranking in this latter approach were apparent nitrification (0.3), humic matter (1.0), extractable acidity (1.9), extractable S (2.0), residual soil $\mathrm{NO}_{3}(2.8)$, and extractable $\mathrm{P}$ (2.8). Therefore, total and mineralizable C and $\mathrm{N}$ fractions of soil appear to be broadly applicable indicators of change in soil properties across a diversity of management conditions and soil types.
Specific to soil health functioning, nutrient cycling to supply $\mathrm{N}$ to growing plants over time was found to be highly predictable from soil-test biological activity, total soil $\mathrm{N}$, and residual inorganic $\mathrm{N}$ (Franzluebbers and Pershing 2018). As well, in an evaluation of pastures in North Carolina, soil-test biological activity, total soil N, and MehlichIII extractable $\mathrm{P}$ and $\mathrm{K}$ were found to be valuable, and mostly independent, indicators of field-scale $\mathrm{C}, \mathrm{N}, \mathrm{P}$, and $\mathrm{K}$ distribution (Franzluebbers et al. 2019).

When soil properties were averaged across the six replications for each cover crop treatment, soil depth, field, and year of sampling, soil-test biological activity had a strong linear association with net $\mathrm{N}$ mineralization (figure $3 \mathrm{~b}$ ). Such strong association has been observed before (Franzluebbers et al. 2007; 2018). Even across soils from other regions of the United States, as well as from tropical regions in other countries, the slope estimate relating the quantity of $\mathrm{N}$ mineralized per unit of soil-test biological activity was very close to that shown in figure $3 \mathrm{~b}$ (Franzluebbers 2018a). Therefore, this rapid and reliable indicator of soil biological activity has great potential in making soil health assessments under a diversity of environmental conditions, and certainly within conservation agricultural systems with multispecies cover cropping as in this study. Indeed, data from this study also revealed some previously unrecognized associations of soil-test biological activity with other soil properties. For example, soil-test biological activity was negatively associated with sieved density (figure 3a), which is influenced by increasing soil organic matter content that reduces soil density. Sieved density was also strongly associated with total organic $\mathrm{C}(r=$ $-0.80)$, clay concentration $(r=-0.80)$, and sand concentration $(r=0.76)$. Soil-test biological activity was positively associated with cation exchange capacity (figure 3c), which is also influenced directly by texture $(r=$ -0.77 with sand concentration) and organic matter $(r=0.72$ with total soil N). Finally, soil-test biological activity was strongly associated with residual soil $\mathrm{NH}_{4}$ (figure $3 \mathrm{~d}$ ). It might be tempting to use these correlations outside of this data set to assess soil health conditions, but the case for residual soil $\mathrm{NH}_{4}$ is a good one to suggest otherwise. Residual soil $\mathrm{NH}_{4}$ can also be highly variable among soil types, management systems, and especially with variable $\mathrm{N}$ fertilizer inputs. The 


\section{Figure 3}

Soil-test biological activity (STBA) in association with (a) sieved density (SD), (b) net nitrogen mineralization (NMIN), (c) cation exchange capacity (CEC), and (d) residual soil ammonium (RSA). SE is standard error of estimate from regression.

(a)

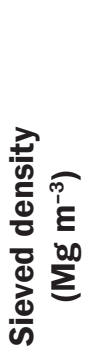

(c)

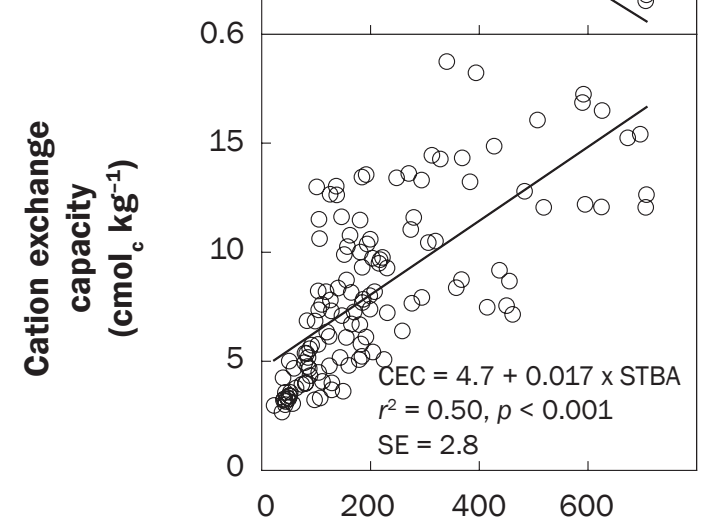

(b)

(d)

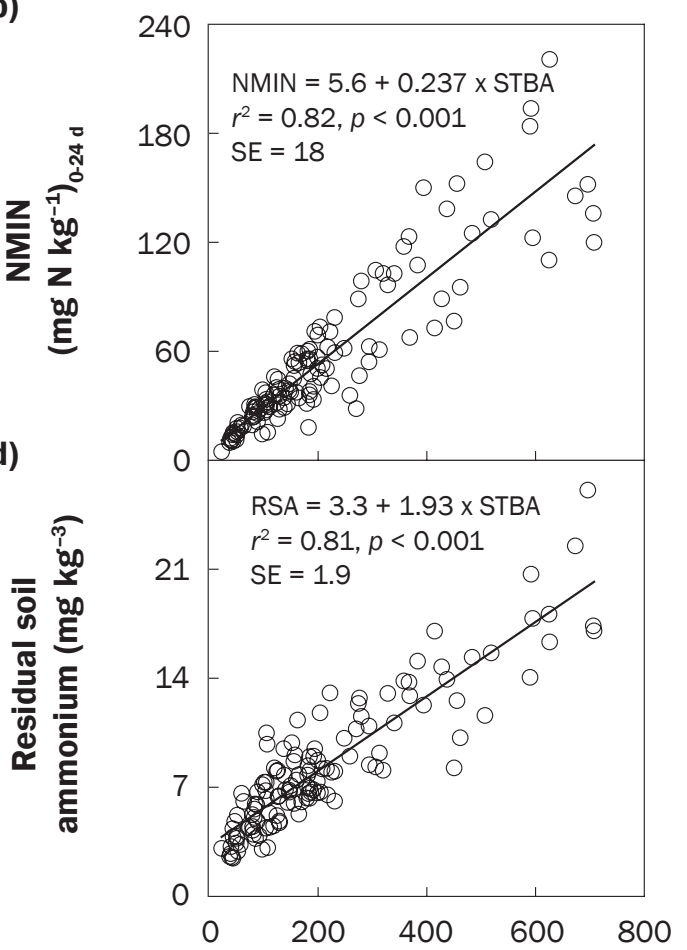

Soil-test biological activity $\left(\mathrm{mg} \mathrm{CO}_{2}-\mathrm{C} \mathrm{kg}^{-1}\right)_{0-3 \mathrm{~d}}$

Soil-test biological activity $\left(\mathrm{mg} \mathrm{CO}_{2}-\mathrm{C} \mathrm{kg}^{-1}\right)_{0-3 \mathrm{~d}}$

fact that residual soil $\mathrm{NH}_{4}$ was narrowly constrained in this study to $<24 \mathrm{mg} \mathrm{kg} \mathrm{m}^{-1}$ suggests that the winter growth period with cover crop uptake of inorganic $\mathrm{N}$ and without recent $\mathrm{N}$ fertilizer inputs provided ideal conditions to create a low level of residual soil $\mathrm{NH}_{4}$ reflective of the strong net $\mathrm{N}$ mineralization gradient (Norton 2000). In addition, oven-drying soil prior to inorganic $\mathrm{N}$ extraction facilitates release of $\mathrm{NH}_{4}$ from actively processed organic matter. The caution with using residual soil $\mathrm{NH}_{4}$ as a potential indicator is also because of its relatively low concentration compared with net $\mathrm{N}$ mineralization, suggesting that it would be difficult to obtain robust interpretation. Of course, many soil properties measured in combination with others will provide greater level of insight.

\section{Summary and Conclusions}

Multispecies cover crop biomass production was sufficient to meet conservation goals in at least $66 \%$ of the 35 field trials in North Carolina. Nitrogen accumulation in multispecies cover crop biomass reached excellent levels at $>60 \mathrm{~kg} \mathrm{~N} \mathrm{ha}^{-1}$ in a third of trials. Since trials were relatively short term (mostly one to two years and as long as four years), we didn't anticipate seeing many soil differences, but there were some of notable significance. Soil-test biological activity, cumulative C mineralization, total soil $\mathrm{N}$, and MehlichIII-extractable $\mathrm{P}$ and $\mathrm{K}$ were soil properties most affected by multispecies cover cropping compared with no cover crop or with single-species cover cropping. Soil-test biological activity and total soil $\mathrm{N}$ were also the dominant soil properties that had strongest associations with several other soil properties, and therefore, were reflective of overall soil health changes in conservation cropping systems. Although we expected more numerous and dramatic changes in the surface 0 to 5 $\mathrm{cm}$ depth, we also found several changes in the 5 to $15 \mathrm{~cm}$ depth. With sufficient biomass production, multispecies cover cropping can help improve soil health condition by fostering soil biological activity and nutrient cycling. Our results indicate that multispecies cover crops are not without challenges, but growers in North Carolina can make this agro-ecological approach work more often than not. The incremental improvements in soil health that we observed on these farms will potentially lead to greater agricultural resilience in the face of external challenges to farm sustainability.

\section{Acknowledgements}

Ellen Leonard, Ashtyn Mizelle, Erin Silva, and Ashley Turner provided sound technical support for plant and soil analyses. We appreciate the Soil Testing Laboratory of the North Carolina Department of Agriculture and Consumer Services for conducting soil chemical analyses. We thank local North Carolina Soil and Water Conservation District staff for working directly with farmer participants to establish research and demonstration sites on farms, including James Allen, Vicki Baker, Clint Brooks, Mamie Caison, Andrew Cox, Bryan Evans, Rod Gurganus (NC Extension), Dwayne Faircloth, Henry Faison, Elizabeth Hamm, Melanie Harris, Valerie Harris, Scott Kiser, Brian Lannon, Edward Long, Will Mann, Andy Miller, Brad Moore, Ken Morris, Emily Pohlman, Jessica Pope, Chris Santelle, Chris Sloop, Rachel Smith, Roger Toledo (USDA NRCS), and Josh Vetter. We are grateful to participating farmers, including Clevie Averett, Todd Boyd, Robert Glover, Louis and Quinn Howard, Ryan Huffman, Joseph Johnson, Rich Kitchin, 
Franklin Lee, Darrell Pate, Michael Shepherd, Keith Sink, Alton Skinner, Sam Smith, Jason Staples, Jeffrey Tyson, and Phillip Whitaker. Funding was provided by USDA Agricultural Research Service and grants from USDA NRCS Conservation Innovation Grant No. 69-3A75-14233, Cotton Incorporated Agreement No. 13-820, USDA Sustainable Agriculture Research and Education Grant No. 2017-38640-26914, and NC Agriculture Development and Farmland Preservation Trust Fund Contract 17-074-4015.

\section{References}

Bundy, L.G., and J.J. Meisinger. 1994. Nitrogen availability indices. In Methods of Soil Analysis: Part 2. Microbiological and Biochemical Properties, SSSA Book Ser. 5, ed. R.W. Weaver, S. Angle, P. Bottomley, D. Bezdicek, S. Smith, A. Tabatabai, and A. Wollum, p. 951 984. Madison, WI: Soil Science Society of America.

Chu, M., S. Jagadamma, F.R. Walker, N.S. Eash, M.J. Buschermohle, and L.A. Duncan. 2017. Effect of multispecies cover crop mixture on soil properties and crop yield. Agricultural and Environmental Letters 2:170030.

Deiss, L., A.J. Franzluebbers, and A. de Moraes. 2017. Soil texture and organic carbon fractions predicted from near-infrared spectroscopy and geostatistics. Soil Science Society of America Journal 81:1222-1234.

Ewing, R.P., M.G. Wagger, and H.P. Denton. 1991. Tillage and cover crop management effects on soil water and corn yield. Soil Science Society of America Journal 55:1081-1085.

Filip, Z., and M. Tesarova. 2005. Microbial processing of humic substances from meadow and forest soils. In Tree Species Effects on Soils: Implications for Global Change, ed. D. Binkley and O. Menyailo, p. 193-212. The Netherlands: Dordrecht.

Finney, D.M., J.S. Buyer, and J.P. Kaye. 2017. Living cover crops have immediate impacts on soil microbial community structure and function. Journal of Soil and Water Conservation 72(4):361-373. https://doi. org/10.2489/jswc.72.4.361.

Finney, D.M., and J.P. Kaye. 2017. Functional diversity in cover crop polycultures increases multifunctionality of an agricultural system. Journal of Applied Ecology 54:509-517.

Franzluebbers, A.J. 2016. Should soil testing services measure soil biological activity? Agricultural and Environmental Letters 1:150009.

Franzluebbers, A.J. 2018a. Short-term C mineralization (aka the flush of $\mathrm{CO}_{2}$ ) as an indicator of soil biological health. CAB Reviews 13:017.

Franzluebbers, A.J. 2018b. Soil-test biological activity with the flush of $\mathrm{CO}_{2}$ : III. Corn yield responses to applied nitrogen. Soil Science Society of America Journal 82:708-721.

Franzluebbers, A.J. 2020. Soil-test biological activity with the flush of $\mathrm{CO}_{2}: \mathrm{V}$. Validation of nitrogen prediction for corn production. Agronomy Journal doi:10.1002/ agj2.20094

Franzluebbers, A.J., G.W. Langdale, and H.H. Schomberg. 1999. Soil carbon, nitrogen, and aggregation in response to type and frequency of tillage. Soil Science Society of America Journal 63:349-355.

Franzluebbers, A.J., and M.R. Pershing. 2018. Soil-test biological activity with the flush of $\mathrm{CO}_{2}$ : II. Greenhouse growth bioassay from soils in corn production. Soil Science Society of America Journal 82:696-707.

Franzluebbers, A.J., M.R. Pershing, C. Crozier, D. Osmond, and M. Schroeder-Moreno. 2018. Soil-test biological activity with the flush of $\mathrm{CO}_{2}: \mathrm{I}$. C and $\mathrm{N}$ characteristics of soils in corn production. Soil Science Society of America Journal 82:685-695.

Franzluebbers, A.J., M.H. Poore, S.R. Freeman, and J.R. Rogers. 2019. Soil-surface nutrient distributions in grazed pastures of North Carolina. Journal of Soil and Water Conservation 74(6):571-583. https://doi. org/10.2489/jswc.74.6.571.

Franzluebbers, A.J., H.H. Schomberg, and D.M. Endale. 2007. Surface-soil responses to paraplowing of longterm no-tillage cropland in the Southern Piedmont USA. Soil and Tillage Research 96:303-315.

Hardy, D.H., M.R. Tucker, and C.E. Stokes. 2014. Crop fertilization based on North Carolina soil tests. Circular No. 1. Raleigh, NC: North Carolina Department of Agriculture and Consumer Services, Agronomic Division. http://www.ncagr.gov/agronomi/obook.htm. Hunter, M.C., M.E. Schipanski, M.H. Burgess, J.C. LaChance, B.A. Bradley, M.E. Barbercheck, J.P. Kaye, and D.A. Mortensen. 2019. Cover crop mixture effects on maize, soybean, and wheat yield in rotation. Agricultural and Environmental Letters 4:180051.

Kaye, J., D. Finney, C. White, B. Bradley, M. Schipanski, M. Alonso-Ayuso, M. Hunter, M. Burgess, and C. Mejia. 2019. Managing nitrogen through cover crop species selection in the U.S. mid-Atlantic. PLoS One 14:e0215448

Keene, C.L., W.S. Curran, J.M. Wallace, M.R. Ryan, S.B. Mirsky, M.J. VanGessel, and M.E. Barbercheck. 2017. Cover crop termination timing is critical in organic rotational no-till systems. Agronomy Journal 109:272-282

Lemaire, G., M.-H. Jeuffroy, and F. Gastal. 2008. Diagnosis tool for plant and crop $\mathrm{N}$ status in vegetative stage: Theory and practices for crop $\mathrm{N}$ management. European Journal of Agronomy 28:614-624.

Mbuthia, L.W., V. Acosta-Martinez, J. DeBruyn, S. Schaeffer, D. Tyler, E. Odoi, M. Mpheshea, and F. Walker. 2015 Long-term tillage, cover crop, and fertilization effects on microbial community structure, activity: Implications for soil quality. Soil Biology and Biochemistry 89:24-34 Mehlich, A. 1984a. Mehlich-3 soil test extractant: A modification of Mehlich-2 extractant. Communications in Soil Science and Plant Analysis 15:1409-1416.
Mehlich, A. 1984b. Photometric determination of humic matter in soils, a proposed method. Communications in Soil Science and Plant Analysis 15:1417-1422.

Mitchell, J.P., A. Shrestha, K. Mathesius, K.M. Scow, R.J. Southard, R.L. Haney, R. Schmidt, D.S. Munk, and W.R. Horwath. 2017. Cover cropping and no-tillage improve soil health in an arid irrigated cropping system in California's San Joaquin Valley, USA. Soil and Tillage Research 165:325-335.

Norton, J.M. 2000. Nitrogen mineralization immobilization turnover. In Handbook of Soil Science, ed. M.E. Sumner, p. C148-C160. Boca Raton, FL: CRC Press.

NRC (National Research Council). 2010.Toward sustainable agricultural systems in the $21^{\text {st }}$ century. Washington, DC: The National Academies Press.

Ranells, N.N., and M.G. Wagger. 1997. Grass-legume bicultures as winter annual cover crops. Agronomy Journal 89:659-665.

Sainju, U.M., H.H. Schomberg, B.P. Singh, W.F. Whitehead, G. Tillman, and S.L. Lachnicht-Weyers. 2007. Cover crop effect on soil carbon fractions under conservation tillage cotton. Soil and Tillage Research 96:205-218.

Smith, R.G., L.W.Atwood, and N.D.Warren. 2014. Increased productivity of a cover crop mixture is not associated with enhanced agroecosystem services. PLoS One 9:e97351.

Snapp, S.S., S.M. Swinton, R. Labarta, D. Mutch, J.R. Black, R. Leep, J. Nyiraneza, and K. O'Neil. 2005. Evaluating cover crops for benefits, costs and performance within cropping system niches. Agronomy Journal 97:322-332.

Stott, D.E. 2019. Recommended soil health indicators and associated laboratory procedures. Soil Health Technical Note No. 450-03. Washington, DC: USDA Natural Resources Conservation Service.

Unger, P.W., and M.F. Vigil. 1998. Cover crop effects on soil water relationships. Journal of Soil and Water Conservation 53(3):200-207.

USDA NRCS (Natural Resources Conservation Service). n.d. Soil Health. Washington, DC: USDA NRCS. https://www.nrcs.usda.gov/wps/portal/nrcs/main/ soils/health/.

Voroney, R.P., and E.A. Paul. 1984. Determination of $\mathrm{kC}$ and $\mathrm{kN}$ in situ for calibration of the chloroform fumigationincubation method. Soil Biology and Biochemistry 16:9-14.

Wagger, M.G. 1989a. Cover crop management and nitrogen rate in relation to growth and yield of no-till corn. Agronomy Journal 81:533-538.

Wagger, M.G. 1989b. Time of desiccation effects on plant composition and subsequent nitrogen release from several winter annual cover crops. Agronomy Journal 81:236-241. 